\title{
A new Ordovician astylospongiid sponge (Porifera) as an erratic from Baltica
}

\section{F. Rhebergen}

Slenerbrink 178, 7812 HJ Emmen, The Netherlands. E-mail: freek.rhebergen@planet.nl

Manuscript received: April 2004; accepted: October 2004

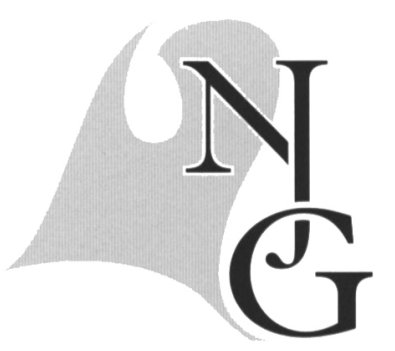

\begin{abstract}
Until now hemispherical astylospongiid sponges were invariably referred to as Caryospongia juglans var. basiplana Rauff. Renewed investigations have now shown that part of the material should be assigned to a new genus and species, Tympanospongia vankempeni, which is characterised by a system of very irregular canals. These flat-based sponges originate from the Baltic region and occur in two assemblages of silicified Late Ordovician sponges known exclusively as erratics from The Netherlands and northern Germany. These fossils were transported by the River Eridanos, a former drainage system from the Baltic region that filled the North European Basin during the Miocene to Early Pleistocene. Specimens of Tympanospongia vankempeni gen. et sp. nov. also occur in the Upper Pleistocene of Gotland, Sweden. The new sponge described herein principally differs from other genera of the Astylospongiidae found frequently in the erratic sponge assemblages by its irregular system of apochetes which ramify and anastomose commonly.
\end{abstract}

Keywords: Porifera, astylospongiids, Baltica, erratics, Late Ordovician, new taxa

\section{Introduction}

Fluvial deposits in The Netherlands and northern Germany have yielded thousands of erratic sponges of Middle and Late Ordovician age (Van Kempen, 1978), as part of two distinct assemblages of erratic silicifications, also comprising tabulates and stromatoporoids. They originate from unknown areas in the Baltic and were transported long before Pleistocene glaciers extended over this area. A large fluvial system, the Eridanos River system (Overeem et al., 2001), drained the Baltic since the Early Miocene. It deposited huge masses of sand, pebbles and boulders, known as the Baltic Gravel Association (BGA) (Bijlsma, 1981), in the German-Polish Basin and, fanning westwards, in the North Sea Basin.

This BGA is known from intermediate strata between Miocene lignite layers in the Lausitz area, southeast of Berlin, Germany (Bijlsma, 1981; Krueger, 1994) and from Pliocene to Lower Pleistocene deposits until recently exposed in sandpits on the island of Sylt, northern Germany (Von Hacht, 1985, 1994; Von Hacht \& Rhebergen, 1996).

During the Early to Middle Pleistocene the BGA lost its characteristic composition, getting mixed with material from the German-Czech Mittelgebirge transported by the main tributaries of the Eridanos River system, such as the proto-Elbe. These mixed sediments were deposited in the Eridanos delta, which by that time extended into The Netherlands and the present North Sea (Zandstra, 1971; Laban, 1995). They are exposed in sandpits in the northeast Netherlands and adjacent German territory, informally known as the WWW area after the villages of Wilsum-Wielen-Westerhaar (Rhebergen \& Von Hacht, 1996) (see Fig. 1). 


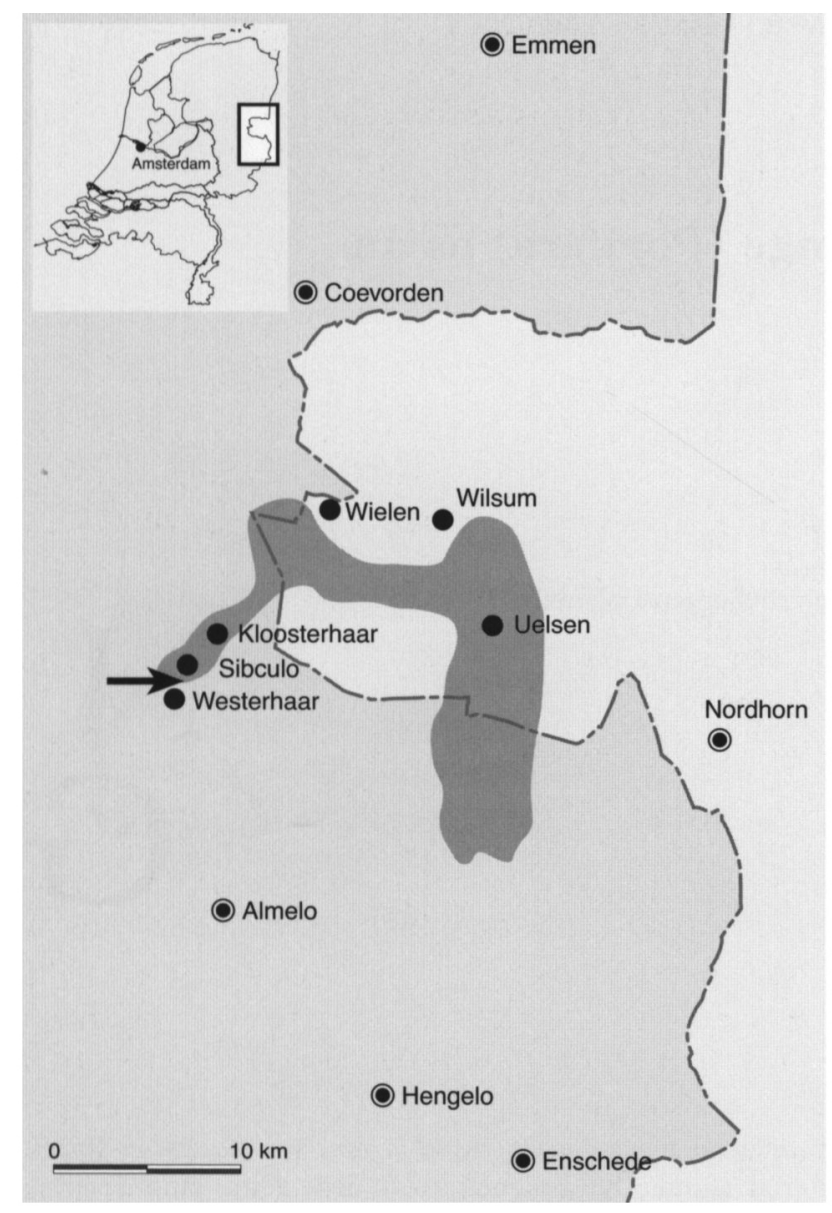

Fig. 1. Dutch-German border area providing most of the specimens of Tympanospongia vankempeni gen. et sp. nov. The shaded area indicates the Late Pleistocene ice-pushed ridges, in which Early Pleistocene fluvial sediments are exposed. The arrow indicates the location of the complex of sandpits between the villages Westerhaar and Sibculo, in which the holotype and the specimens X-248, X-334 and X-335 have been collected.

In Table 1 the composition of the sponge assemblages has been summarized. The genera of three families of the order Orchocladina Rauff, 1894 (classification after Rigby, 2004) and the genera and species of the Astylospongiidae Zittel, 1897 have been listed. The latter, since Tympanospongia vankempeni gen. et sp. nov. belongs to this family.

Differences in the composition of sponge assemblages from the Lausitz area and Sylt on the one hand, and those from the WWW area on the other were discussed by Von Hacht \& Rhebergen (1997). The palaeogeographical position of Baltica during the Ordovician (McKerrow et al., 1991) and the palaeobiology of Ordovician sponges (e.g., Johns, 1994) may help explain these differences. Anthaspidellids, supposedly of Middle to Late Ordovician age, predominate among erratic sponges from the Lausitz area and Sylt and probably originate from outer shelf areas and upper slopes along the northern margins of Baltica. The sponges from the WWW area are chiefly
Table 1. Composition of the Ordovician erratic sponge assemblage occurring in the Netherlands, northern Germany and on the Island of Gotland, Sweden (classification after Rigby, 2004).

\begin{tabular}{|c|c|}
\hline Phylum & Porifera Grant, 1836 \\
\hline Class & Demospongea Sollas, 1875 \\
\hline Subclass & Lithistida Schmidt, 1870 \\
\hline Order & Orchocladina Rauff, 1894 \\
\hline Family & Anthaspidellidae Miller, 1889 \\
\hline Genus & $\begin{array}{l}\text { Anthaspidella Ulrich \& Everett, } 1890 \\
\text { Archaeoscyphia Hinde, } 1889 \\
\text { Calycocoelia Bassler, } 1927 \\
\text { Diotricheum } \text { Van Kempen, } 1989 \\
\text { Fibrocoelia Van Kempen, } 1978 \\
\text { Nevadocoelia Bassler, } 1927 \\
\text { Patellispongia Bassler, } 1927 \\
\text { Schismospongia Rhebergen \& von Hacht, } 2000 \\
\text { Vankempenia von Hacht, } 1994\end{array}$ \\
\hline Family & Streptosolenidae Johns, 1994 \\
\hline Genus & $\begin{array}{l}\text { Streptosolen Ulrich \& Everett, } 1890 \\
\text { Aulocopium Oswald, } 1847 \\
\text { Aulocopella Rauff, } 1894 \\
\text { Hudsonospongia Raymond \& Okulitch, } 1940 \\
\text { Lissocoelia } \text { Bassler, } 1927 \\
\text { Perissocoelia Rigby \& Webby, } 1988\end{array}$ \\
\hline Family & Chiastoclonellidae Rauff, 1893 \\
\hline Genus & $\begin{array}{l}\text { Chiastoclonella Rauff, } 1893 \\
\text { Syltispongia van Kempen, } 1990\end{array}$ \\
\hline Family & Astylospongiidae Zittel, 1877 \\
\hline Genus and species & $\begin{array}{l}\text { Astylospongia praemorsa (Goldfuss, 1826) } \\
\text { A. incisolobata Roemer, } 1860 \\
\text { Caryospongia juglans (Quenstedt, 1878) } \\
\text { C. edita (Klöden, 1834) } \\
\text { C. diadema (Klöden, 1834) } \\
\text { C. roemeri (Hinde, 1883) } \\
\text { Carpospongia globosa (Eichwald, 1830) } \\
\text { C. castanea (Roemer, 1861) } \\
\text { C. langei von Hacht, } 1994 \\
\text { C. conventzi Rauff, } 1893 \\
\text { C. stellatimsulcatum (Roemer, 1848) } \\
\text { Caryoconus gothlandicus (Schlüter, 1884) } \\
\text { Syltrochos pyramidoidalis von Hacht, 1981 } \\
\text { Tympanospongia vankempeni gen. et sp. nov. }\end{array}$ \\
\hline Subclass & Tetractinomorpha Lévi, 1953 \\
\hline Order & Streptosclerophorida Dendy, 1924 \\
\hline Suborder & Eutaxicladina Rauff, 1893 \\
\hline Family & Hindiidae Rauff, 1893 \\
\hline Genus and species & s Hindia sphaeroidalis Duncan, 1879 \\
\hline
\end{tabular}

astylospongiids, originating probably from continental basins in the Bothnian Gulf or even further north (Krueger, 1994).

An assemblage of exclusively erratic Ordovician sponges is known from Upper Pleistocene (probably Weichselian) deposits on Gotland, Sweden (Lindström, 1888; Rhebergen \& Von Hacht, 2000). With one exception, bodily preserved sponges in Ordovician solid rock have not been found on the mainland of Sweden (V. Jaanusson, pers. comm., 1997) and occur only rarely in Estonia. The composition of this assemblage closely resembles that from 
the WWW area, but differs from those from the Lausitz area and Sylt (Rhebergen \& Von Hacht, 2000). This agrees with the occurrence of the new sponge genus described herein, which is fairly common in the assemblages from Gotland and the WWW area $(1.4 \%)$, but is rare in those from the Lausitz area and Sylt $(<0.2 \%)$.

A minor sponge assemblage is known from Saalian glacial deposits at Sadewitz, now Zawidowice, east of Wroclaw, Poland (Oswald, 1847; Roemer, 1861). It shows clear similarities to that from Gotland (Rhebergen \& Von Hacht, 2000), but none of the sponges, which we only know from the literature, can be assigned to the species described below.

\section{Inducement and methods}

Generally, Ordovician astylospongiids are globular to subglobular. Rauff (1893) described and depicted a flat-based hemispherical specimen of Caryospongia juglans and considered this shape to be the result of partial erosion. Wiman (1901) referred to an erratic sponge of the same shape, which he identified as Caryospongia juglans var. basiplana Rauff. Apparently Wiman knew that Rauff had changed his mind, but Rauff never mentioned this variation in his papers. As a result, all the collected specimens were identified as C. juglans var. basiplana Rauff in Wiman, 1901. In 1978, Van Kempen examined a number of flat-based specimens which in his opinion had been identified incorrectly. His research resulted in the discovery of an excurrent system unique to astylospongiids (Fig. 2), but his results were never published. Quite recently,

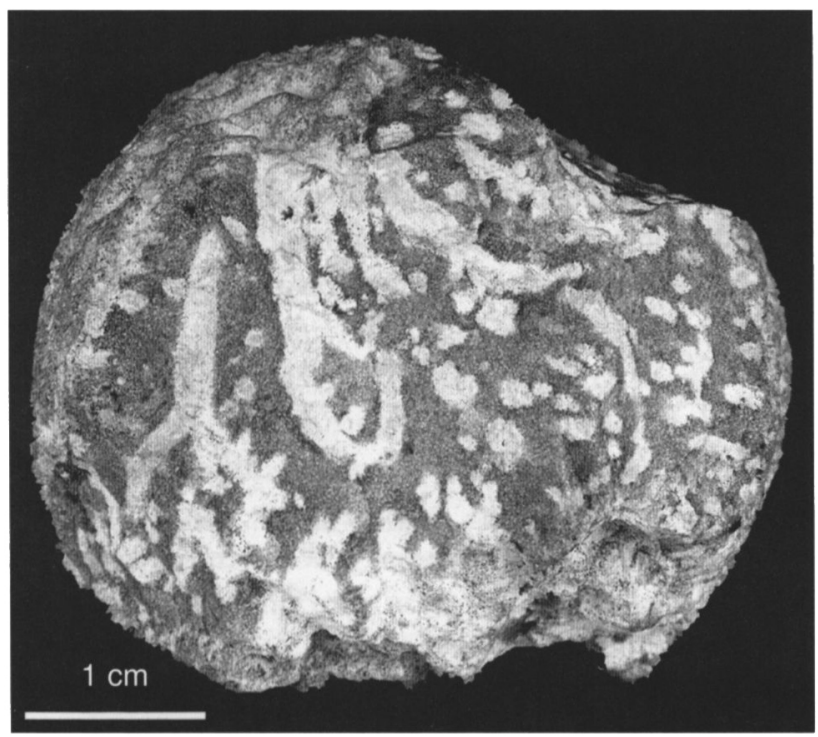

Fig. 2. Tympanospongia vankempeni gen. et sp. nov. Specimen X-334, erratic from Sibculo. One of the median sections showing the irregular system of apochetes.
Van Kempen planned a paper on his discovery in co-operation with the present author, but he died. The present paper is dedicated to the memory of Van Kempen. The systematic part basically reflects his research.

\section{Methods}

Tomography was used on four specimens in order to establish the structure of the in- and excurrent systems, and to examine to what degree the external course of the grooves and that of the internal apochetes are similar. One of the specimens had a slightly conical, two a hemispherical and one a flattened upper part. Three specimens were sectioned and subsequently polished, in several stages, and in each stage the course of the canals was traced directly from the polished surface onto a transparant sheet. Each stage was numbered, the distance from the surface to the centre was measured and, where necessary, the most important canals were numbered as well. Thus, a three-dimensional image of the canal system could be obtained, piling up the series of transparant sheets (Fig. 3). A new series of polishing stages was prepared halfway through the bodies of two sponge specimens, but now at right angles to the first series and similarly documented on transparant sheets. Many canals were filled with a mealy, siliceous powder, which could be removed easily and this made it possible to obtain a rough image of the course of a part of such canals (Fig. 4). Some hundreds of measurements have been made on spicules embedded in locally translucent chalcedony, both directly around the skeletal centre

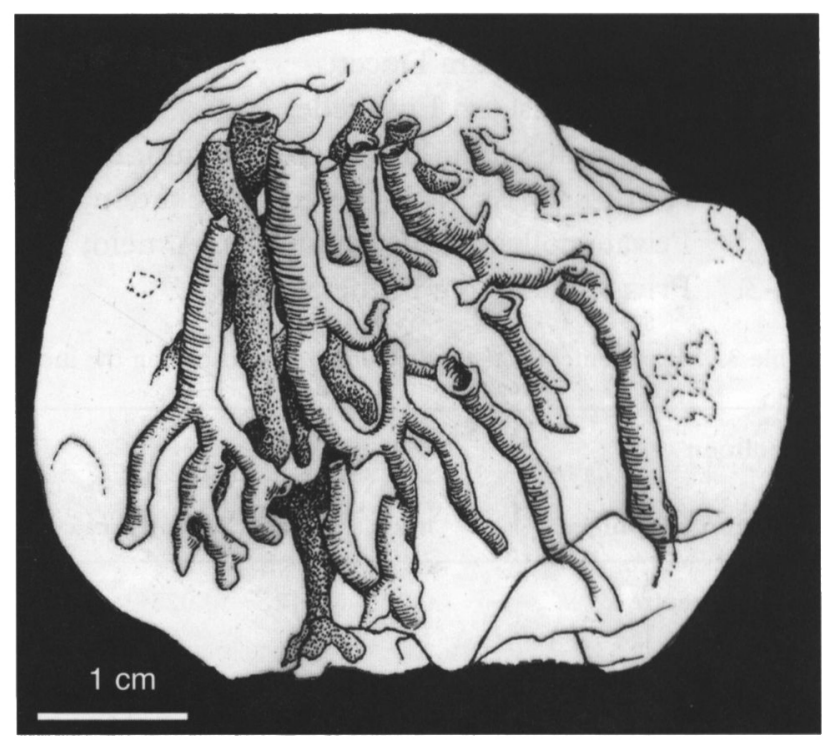

Fig. 3. Tympanospongia vankempeni gen. et sp. nov. Specimen X-334, erratic from Sibculo. Reconstruction of the apochetical system drawn by Van Kempen. It has been obtained by piling up transparent sheets with drawings of 25 sequential polished surfaces. 


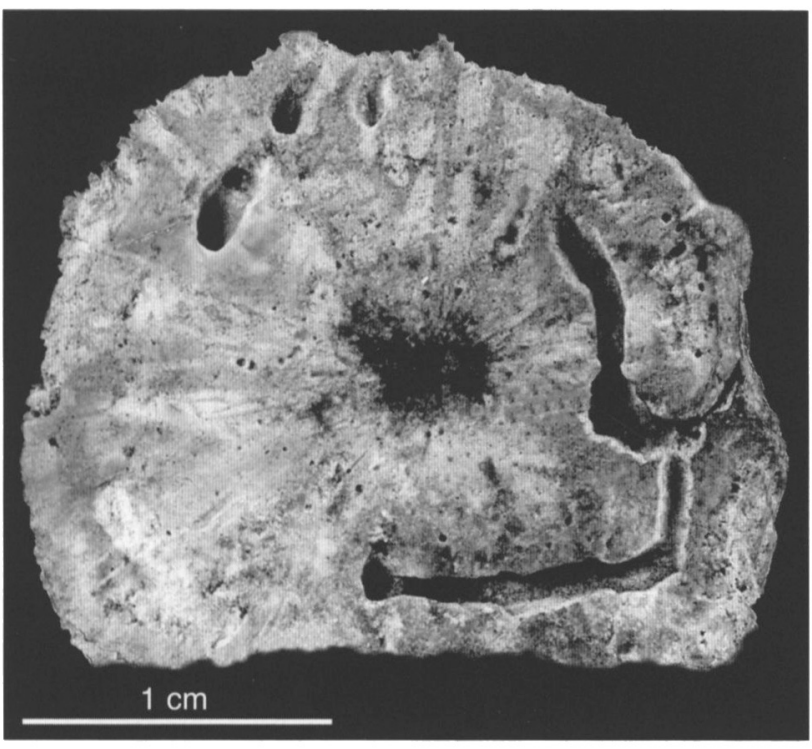

Fig. 4. Tympanospongia vankempeni gen. et sp. nov. Specimen X-248, erratic from Westerhaar. Median section demonstrating the course of some apochetes freed from siliceous, mealy powder.

and in the periphery of the sponge body (Table 2, 3). The remains of three specimens registrated by Van Kempen as X-248, X-334 and X-335, got lost between 1978 and 2002. They were missing in Van Kempen's collection when it moved as a legacy into the Nationaal Natuurhistorisch Museum in Leiden, The Netherlands, in 2002. These specimens are essential to our investigation and will be referred to in this paper by their original identification.

\section{Abbreviations}

EZ Ecodrome Park, Zwolle;

LG Lansmuseet Gotland, Visby, Sweden;

MND Museum Natura Docet;

NE Natuurmuseum Enschede;

NNM Nationaal Natuurhistorisch Museum, Leiden;

NRM Naturhistoriska Riksmuseet, Stockholm;

P1 Private collection W. Zanderink, Almelo;

P2-3 Private collection of the author.
Table 2. Dimensions of Tympanospongia vankempeni gen. et sp. n., in $\mathrm{mm}$.

\begin{tabular}{lllll}
\hline Specimen & \multicolumn{2}{l}{ Diameter Diameter } & Height & $\begin{array}{l}\text { Type } \\
\text { at base } \\
\text { at shoulder }\end{array}$ \\
\hline NNM RGM 283580 & 46 & 55 & 41 & a \\
NNM RGM 283581 & 46 & 59 & 48 & a \\
X-334 & 31 & 45 & 39 & a \\
X-335 & 30 & 40 & 26 & a \\
NRM Sp 2445 & 46 & 68 & 46 & a \\
NRM Sp256 & 36 & 49 & 43 & a \\
NRM Sp518 & $50 / 42$ & 63 & 48 & a \\
LG G 830 & $32 / 25$ & $48 / 37$ & 37 & a \\
LG G 829 & $24 / 19$ & $33 / 30$ & 33 & a \\
EZ Z 25365 & 60 & 70 & 50 & a \\
P1 III-219 & 71 & 88 & 55 & a \\
P2 S 111.33 & 72 & 90 & 60 & a \\
P3 Ue 113.54 & 44 & 64 & 40 & a \\
EZ Z 39727 & 49 & no shoulder & 40 & b \\
X-248 & 24 & no shoulder & 20 & b \\
MND ND62 & 41 & no shoulder & 38 & b \\
NRM Sp1513 & 45 & no shoulder & 43 & b \\
\hline
\end{tabular}

\section{Systematic palaeontology}

$\begin{array}{ll}\text { Class } & \text { Demospongea Sollas, 1875 } \\ \text { Subclass } & \text { Lithistida Schmidt, 1870 } \\ \text { Order } & \text { Orchocladina Rauff, 1894 } \\ \text { Family } & \text { Astylospongiidae Zittel, 1877 }\end{array}$

\section{Tympanospongia gen. nov.}

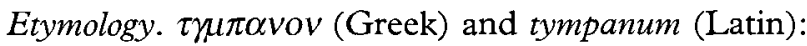
kettledrum. The general sponge form resembles an inverted kettledrum.

Type and only known species. Tympanospongia vankempeni sp. nov.

\section{Diagnosis}

Sponge (sub)cylindrical, conical or obconical, grooved, with flat or concave base. Upper side hemispherical, conical or flattened, with clustering of apopores.

Table 3. Measurements on spheroclones, demonstrating the increasing size from centre to periphery, in mm.

\begin{tabular}{|c|c|c|c|c|c|c|c|c|c|c|c|c|}
\hline \multirow{2}{*}{$\begin{array}{l}\text { Specimen } \\
\text { Location in sponge }\end{array}$} & \multicolumn{3}{|c|}{$X-248$} & \multicolumn{3}{|c|}{ RGM 283580} & \multicolumn{3}{|c|}{$x-334$} & \multicolumn{3}{|c|}{$\mathbf{X}-335$} \\
\hline & $\max$. & min. & diam. & $\max$. & $\min$ & diam. & $\max$. & min. & diam. & $\max$. & $\min$. & diam. \\
\hline $3 \mathrm{~mm}$ fr. centre & 0.27 & 0.12 & 0.025 & & & & & & & & & \\
\hline $4 \mathrm{~mm}$ fr. centre & & & & & & & 0.27 & 0.12 & & & & \\
\hline $5 \mathrm{~mm}$ fr. centre & & & & 0.25 & 0.13 & 0.03 & 0.33 & & 0.02 & & & \\
\hline $7 \mathrm{~mm}$ fr. periphery & & & & & & & 0.43 & 0.15 & 0.035 & & & \\
\hline $6 \mathrm{~mm}$ fr. periphery & & & & & & & & & & 0.41 & 0.20 & 0.04 \\
\hline $5 \mathrm{~mm}$ fr. periphery & 0.30 & 0.17 & 0.035 & & & & & & & & & \\
\hline $4 \mathrm{~mm}$ fr. periphery & & & & 0.032 & 0.13 & 0.04 & & & & & & \\
\hline
\end{tabular}


Spongocoel absent or represented as a shallow apical depression. Lateral grooves irregular, anastomosing and identical to apochetes of the internal excurrent system. Apochetes straight or arcuate, positioned concentrically or vertically, generally running randomly and ramifying in a highly irregular manner. Apopores generally opening into apical area, otherwise distributed over the surface, either confined to the upper part or to the meridional grooves. Radial prosochetes variable in diameter. Skeleton composed of spheroclones, increasing in size from centre to periphery. No dermal specialisation.

\section{Discussion}

Tympanospongia is characterised by its body form (its peculiar flat or concave base is never lacking) and by its apochetal system, which is different from that of any other genus in this family. Rauff (1893, p. 280) distinguished three genera, viz. Astylospongia, Caryospongia and Carpospongia, by the following characteristic differences in the course of the apochetical system; the distribution and location of the apopores, and whether or not the external grooves are in accordance with the internal excurrent system. Three modifications in the course of the apochetes were distinguished (ibid, p. 135): Astylospongia, 'Internal arcuate canals concentric, also in the lower parts parallel to and not emptying into the surface'; Caryospongia, '... arcuate canals bending uniformly to the centre of the sponge'; Carpospongia, 'Only one type of canals present: only straight or nearly straight radial canals have been developed'.

The excurrent systems of Astylospongia and Tympanospongia gen. nov. are clearly distinct. Whereas Astylospongia has a system of mostly uniformly arranged non-anastomosing canals (Fig. 5, median view of $A s t y$ lospongia praemorsa), those of Tympanospongia represent a system that is basically irregular and anastomosing.

Rauff (1893, pp. 130, 131, 135, 294, 313, 318-322) extensively described astylospongiids from Tennessee (USA) and Canada. For practical reasons he used 'quasi genus names' Astylomanon, Caryomanon and Carpomanon, emphasising that he considered these to be identical to the European genera because the apochetical systems were similar. In his revision of the Astylospongiidae, De Laubenfels (1955, pp. 60-61) separated the American astylospongiid genera from the European ones, referring to certain morphological differences, and combined the genus Caryospongia with Carpospongia, both being morphologically as different from each other as the genera he separated. Finks (1960, p. 96, footnote) rejected De Laubenfels's revision.

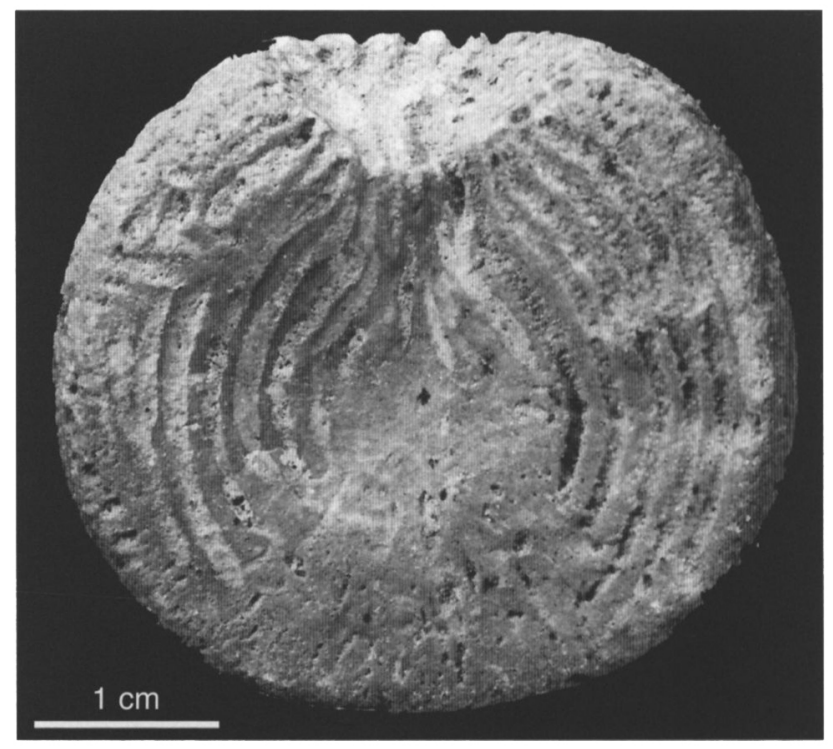

Fig. 5. Astylospongia praemorsa (Goldfuss, 1826), median view, demonstrating the course of the regular, concentric apochetes, which do not enter the surface of the sponge. Erratic from Wilsum, Germany; reg. nr. NE 6300.01155 (coll. J. Jonkman).

The genus Palaeomanon Roemer, 1860 (which is not synonymous with Astylospongia Roemer, 1860) differs from Tympanospongia gen. nov. in that most of its species are pedunculate and obconical, have a sharply rimmed, concave spongocoel and regular, arcuate apochetes comparable to those of Astylospongia (Rauff, 1893, p. 315). The present author has recognised unpublished representatives of Palaeomanon sp. in assemblages of erratic sponges from Gotland, which will be the subject of a future paper.

When Tympanospongia gen. nov. and C. juglans var. basiplana Rauff in Wiman, 1901 are compared, their

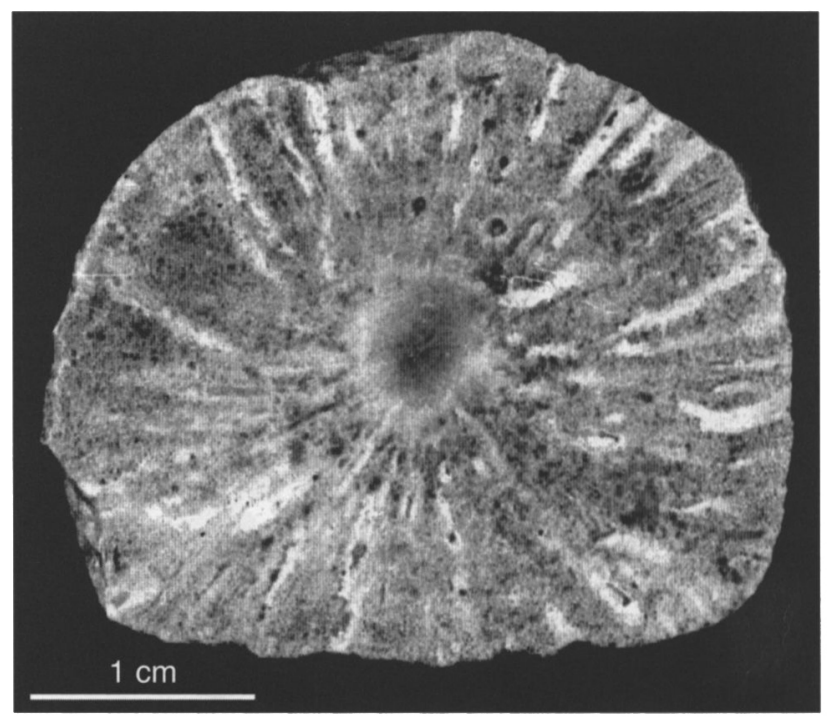

Fig. 6. Median view of Caryospongia juglans var. basiplana Rauff in Wiman, 1901, demonstrating the radially arranged apochetes, which are straight in the basal and flaring upwards in the upper part of the sponge. Erratic from Wilsum, Germany, reg. nr. NE 6300.01154 (coll. T.Koops). 


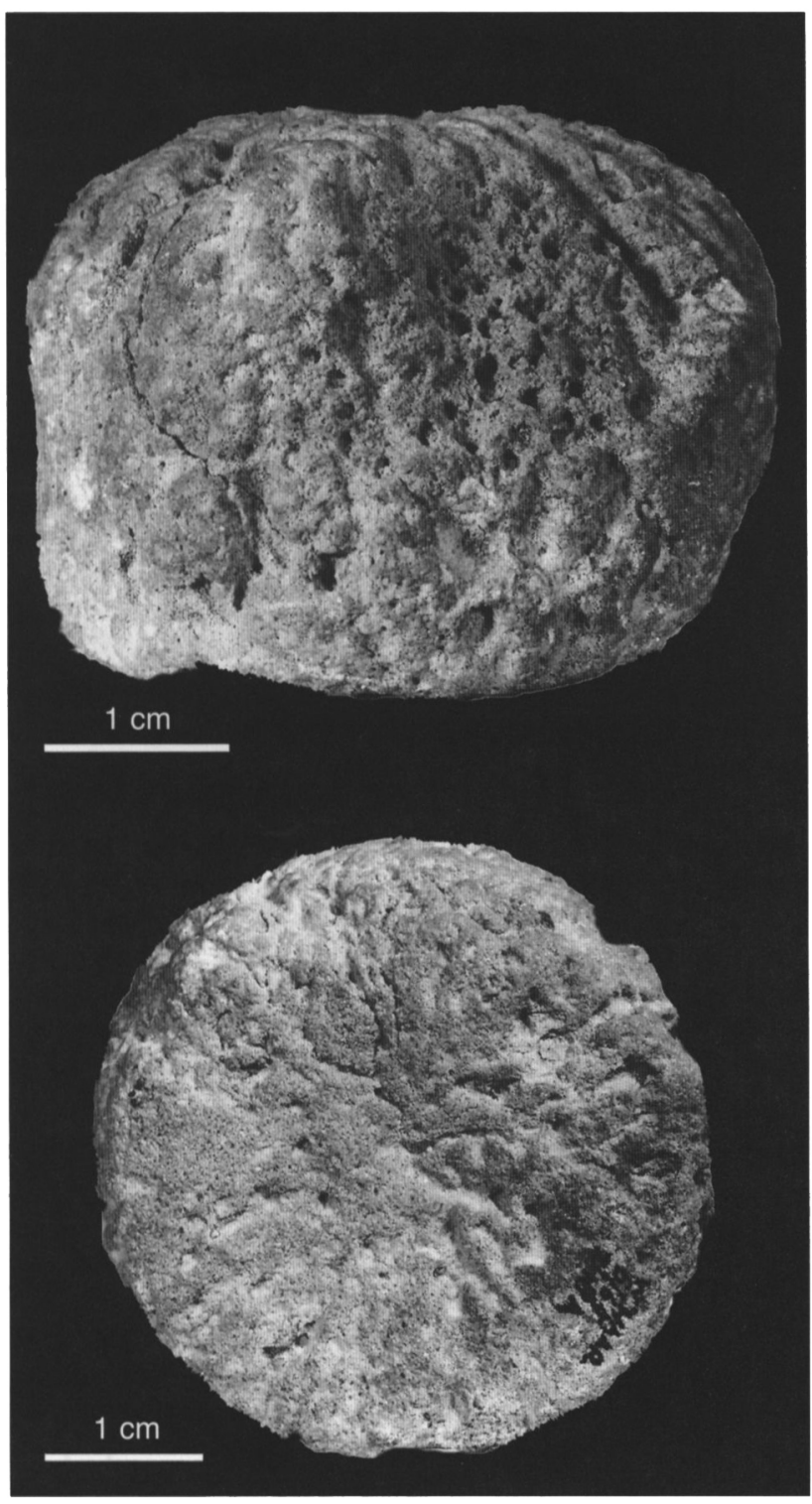

Fig. 7. Tympanospongia vankempeni gen. et sp. nov. Holotype. Lateral and basal view, demonstrating superficial apochetes. Erratic from Westerhaar, reg. nr. NNM RGM 283580 (coll. Van Kempen).

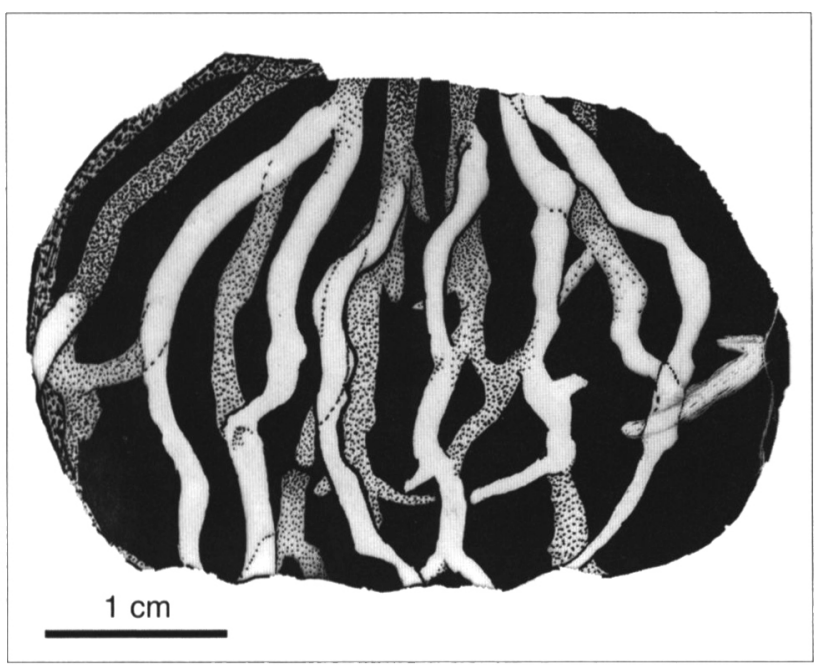

Fig. 8. Tympanospongia vankempeni gen. et sp. nov. Specimen $\mathrm{X}-335$, erratic from Sibculo. Schematic reconstruction of the course of apochetes drawn by Van Kempen. general body forms may be similar, but this feature is subordinate to the differences of the exhalent systems. The latter has radially oriented apochetes running from the centre towards the periphery, straight in the basal part and arcuate in the upper part of the sponge (Fig. 6). It often has a kind of apical knob without, or with only a few scattered apopores and its lateral grooves are not identical to canals of the excurrent system.

Other genera, such as Astylospongiella, Caliculospongia, Camellaspongia, Phialaspongia and Globispongia are also subglobular to subcylindrical, but they all have a conspicuous spongocoel.

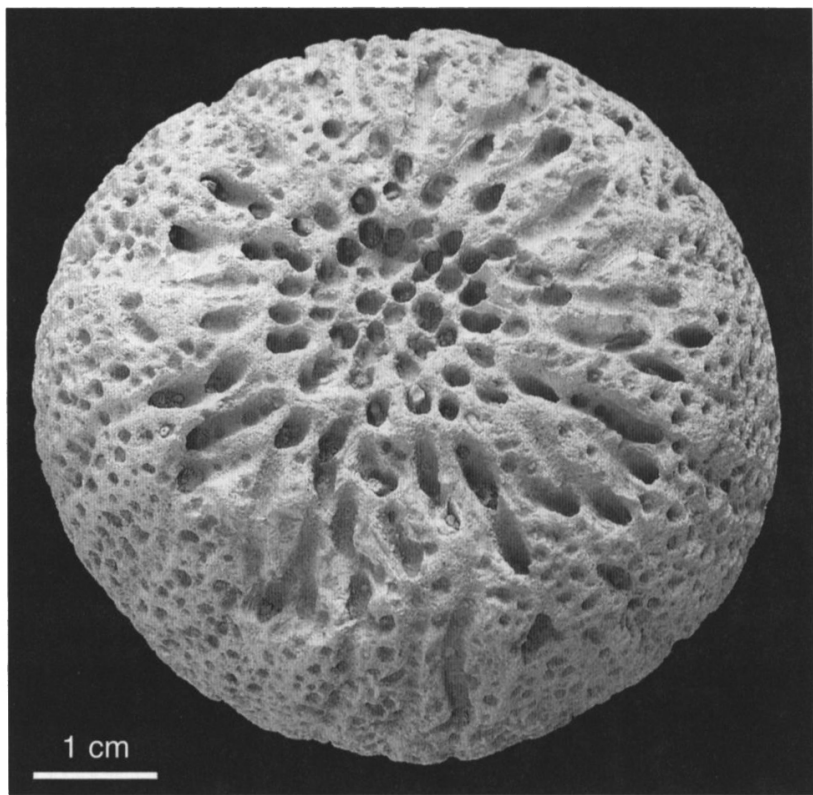

Fig. 9. Tympanospongia vankempeni gen. et sp. nov. Paratype 1 Apical view, demonstrating the radially arranged apopores. Erratic from Gotland, reg. nr. NRM Sp2445.

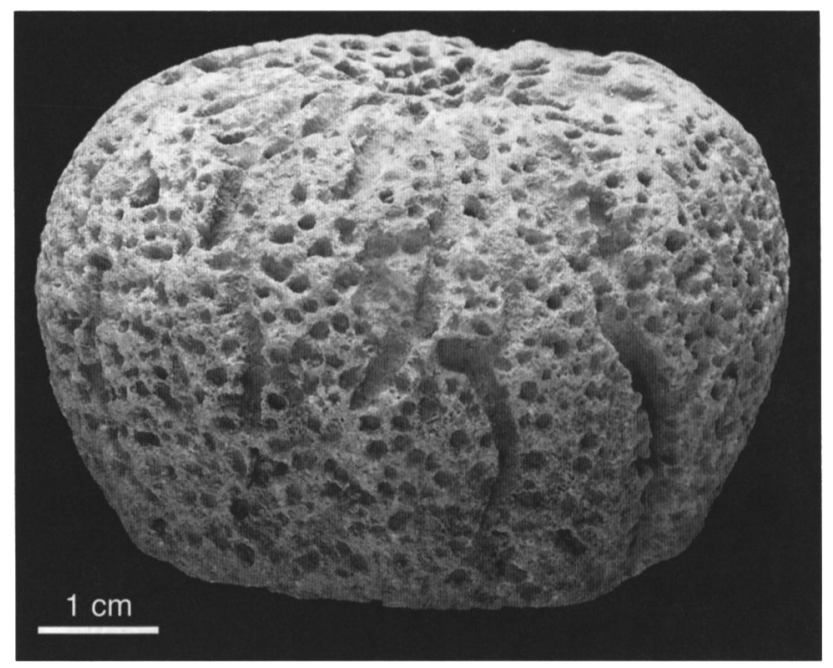

Fig. 10. Tympanospongia vankempeni gen. et sp. nov., same specimen as in Fig. 9, lateral view, demonstrating the irregular, ramifying apochetes. 


\section{Tympanospongia vankempeni sp. nov.}

Figs. 2-4; 7-14.

\section{Synonymy}

Caryospongia juglans Rauff, 1893, p. 299, fig. 63.

Caryospongia juglans var. basiplana Rauff in Wiman, 1901, p. 196.

Caryospongia juglans De Freitas, 1991, p. 2047, fig. 5. Caryospongia juglans var. basiplana Von Hacht \& Rhebergen, 1996, p. 15; Rhebergen \& Von Hacht, 1996, p. 85; Von Hacht \& Rhebergen, 1997, p. 55;

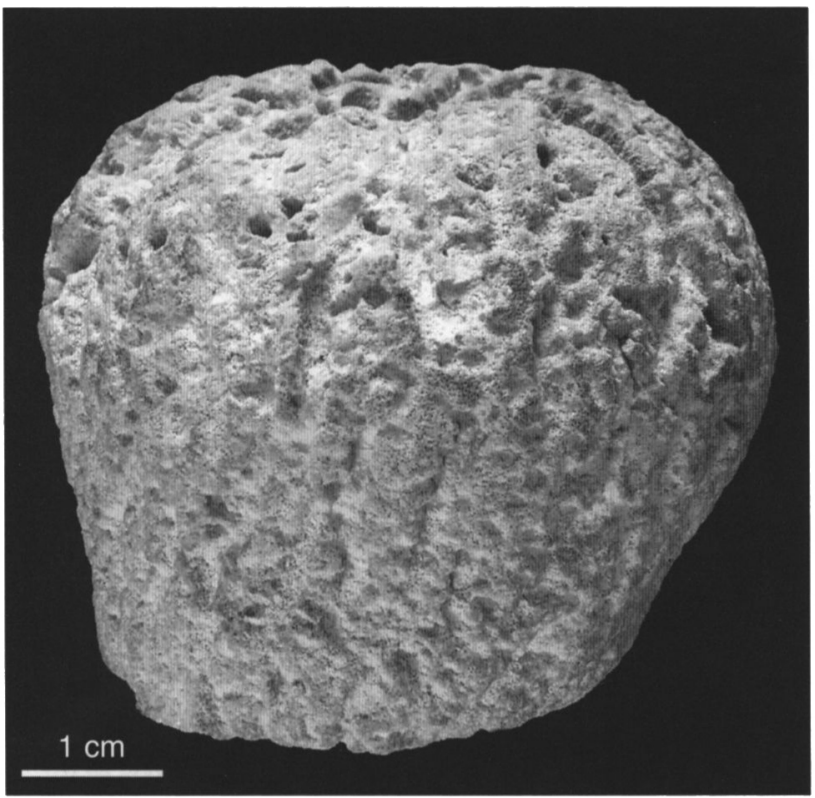

Fig. 11. Tympanospongia vankempeni gen. et sp. nov. Paratype 2 . Lateral view. Erratic from Sibculo, reg. nr. RGM 283581 (coll. Rhebergen).

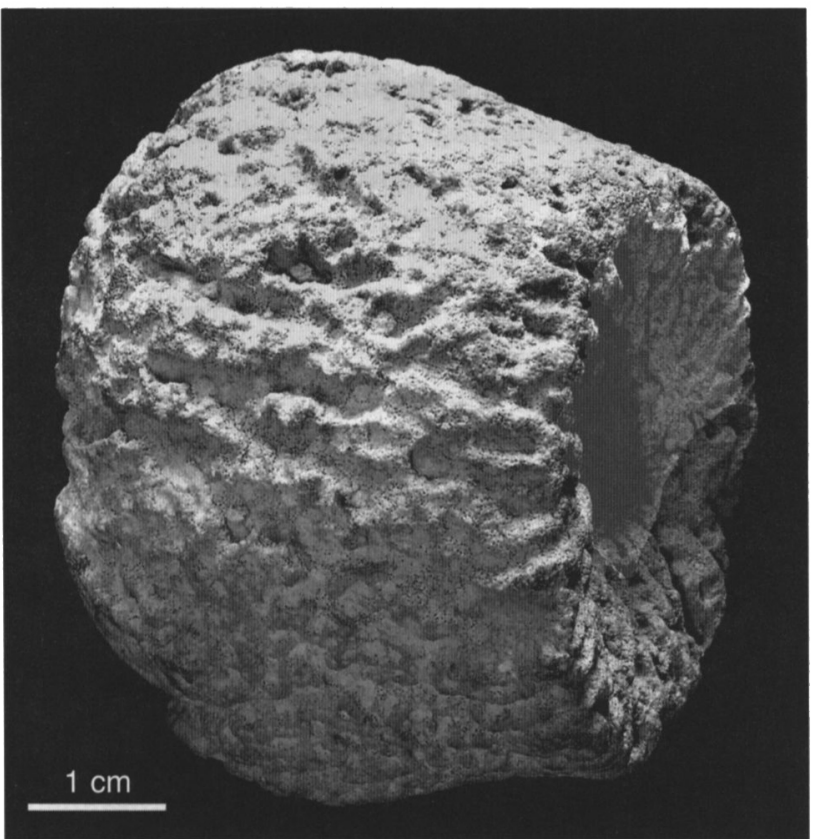

Fig. 12. Tympanospongia vankempeni gen. et sp. nov., same specimen as in Fig. 11, oblique lateral/basal view, demonstrating the concave base.
Rhebergen \& Von Hacht, 2000, p. 343; Rhebergen et al., 2001, pp. 126-127, pl. 36, fig.1-5.

'Astylospongia' sp. A, var. basiplana Rhebergen et al., 2001, pp. 128-129, pl. 37, fig. 1-5.

'Astylospongia' sp. B, var. basiplana Rhebergen et al., 2001, pp. 128-129, pl. 37, fig. 1-5.

Etymology. In honour of the late Th. M.G. van Kempen, who revived, stimulated and supported research of erratic sponges in The Netherlands.

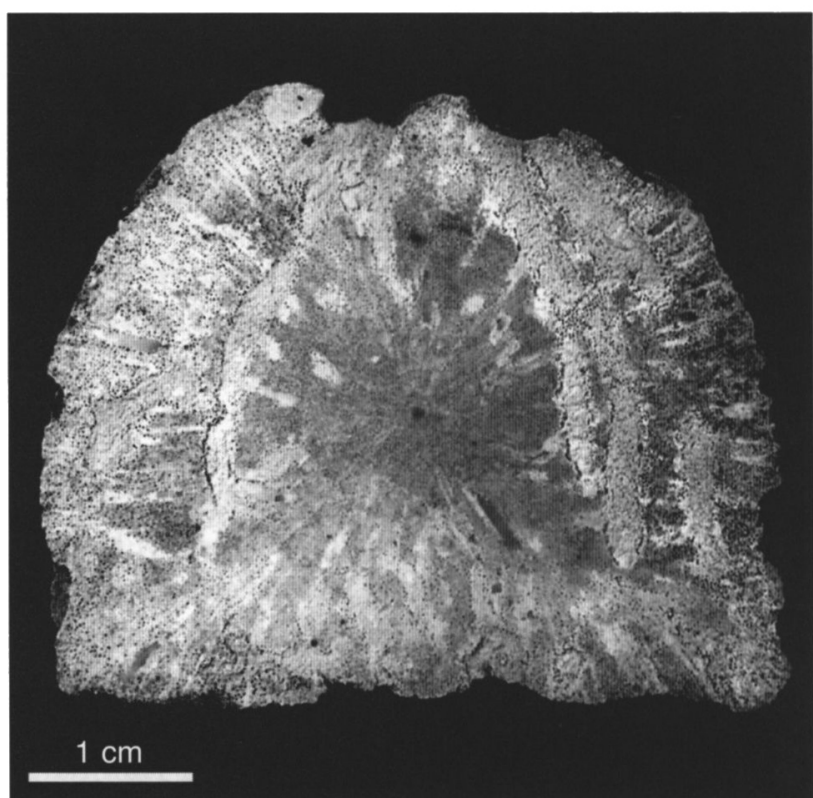

Fig. 13. Tympanospongia vankempeni gen. et sp. nov. Paratype 3 . Median view of a conical to cylindrical specimen of type $b$. Erratic from Westerhaar, reg. nr. EZ Z 39727 (coll. Drent).

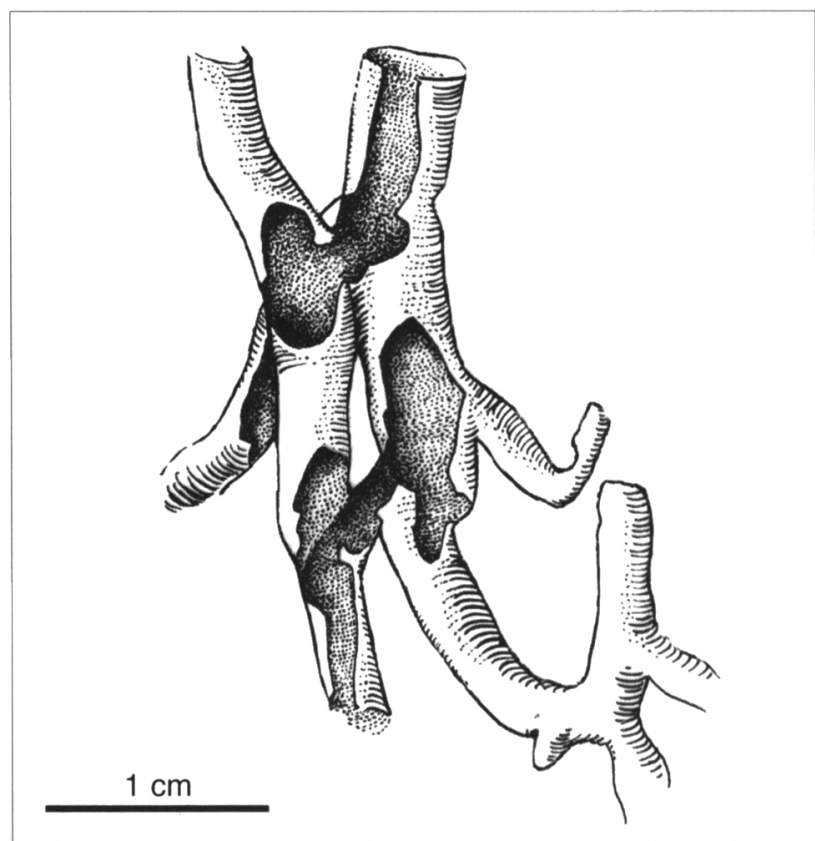

Fig. 14. Tympanospongia vankempeni gen. et sp. nov. Specimen $\mathrm{X}-334$. Example of anastomosing of two apochetical canals drawn by Van Kempen. 
Holotype. RGM 283580; from Westerhaar, The Netherlands. The holotype is $46 \mathrm{~mm}$ wide at the base, $55 \mathrm{~mm}$ at the shoulder and $41 \mathrm{~mm}$ tall (Fig. 7).

Paratype 1: NRM Sp 2445; erratic from Gotland. (Figs. 9, 10).

Paratype 2: RGM 283581 from Westerhaar, The Netherlands. (Figs. 11, 12).

Paratype 3: Z 39727 from Westerhaar, The Netherlands (Fig. 13).

Three specimens from Westerhaar and Sibculo, The Netherlands, numbered by Van Kempen as X-248 (Fig. 4); X-334 (Figs. 2, 3, 14) and X335 (Fig. 8) and sliced several times for tomographical examination have been lost.

Locus typicus. Sandpit near the village of Westerhaar, The Netherlands (N 52 33'; E 6 ${ }^{\circ} 53^{\prime}$ ) (Fig. 1).

\section{Other material}

Circa 60 specimens from Gotland, housed in the NRM, the LG and in the collection of Mrs. Heilwig Leipnitz, Uelzen, Germany. Circa 20 specimens from the island of Sylt, collected by the late U. von Hacht, Hamburg and partly deposited in the Archiv für Geschiebekunde, Geologisch-Paläontologisches Institut and Museum of the University of Hamburg, Germany. Over 200 specimens from the WWW area have been recognised in private and museum collections in The Netherlands.

\section{Diagnosis}

Obconical, (sub)cylindrical, or conical, grooved sponge with short, perpendicular or convexly bent sides. Base flat or concave. Top hemispherical, slightly conical or flattened, with a clustering of apopores. Transition of the base to the sides sharp, that of the sides to the upper part of the body subrounded or smooth, so that they gradually merge into each other. Site of maximum growth on outside usually just below the subrounded top, thus producing some kind of 'shoulder'. Random grooves anastomosing, meeting at the base. Grooves part of the internal excurrent system. Apochetes usually extremely irregular with anastomosis and frequent ramification of the passages. Apochetes open on upper part of the sponge body; apopores 1-3 $\mathrm{mm}$ wide and arranged irregularly or radially. Prosochetes radially oriented to the centre of the sponge. Prosopores up to $1 \mathrm{~mm}$ wide, scattered all over the surface.

\section{Body form}

In the general body form, two types may be distinguished: type $a$ : the obconical to cylindrical, topflattened type, (Figs. 8-12) and type $b$ : the conical to cylindrical, domeshaped type with hemispherical top (Fig. 13). These differences also influence the excurrent systems, as will be described below. However, the conspicuous and consistent differences between body forms and excurrent systems of types $a$ and $b$ cannot be defined specifically, and therefore they are not considered to be distinct species (Table 2).

About $90 \%$ of the specimens belong to type $a$. They are massive, obconical sponges, usually wider than tall, with a flattened to slightly convex top. A slight central cavity, which may occur uncommonly in the flattened top, is produced by a cluster of wide apopores and cannot be interpreted as a spongocoel (Fig. 9). The site of their maximum growth on the outside is situated just below the top. Hence, the sides are generally convexly bent, with an increasing diameter from base to top (Figs. 8, 10, 11). Transition of the base to the sides is sharp. The sides meet the tuberculate base at an angle generally between $105^{\circ}$ and $115^{\circ}$, but can be about $90^{\circ}$. Usually the transition of the sides to the top is subrounded. Rather deep, capricious grooves run from the top downwards along the sides and meet at the base, giving rise to prominent ridges and tubercles that were locally abraded during transport. Usually the base is concave (Fig. 12). The angle in the centre of the base varies from $150^{\circ}$ to $180^{\circ}$. The circular apopores, which are about 1-3 $\mathrm{mm}$ in diameter, are confined to the top and are arranged in more or less regular, radiating rows (Fig. 9 ). When these openings have a lateral disposition, they are usually accompanied by short preliminary grooves which gradually become longer and deeper before entering the body. When they do not enter, but continue as lateral grooves, they give rise to prominent ridges, especially at the point where top and sides meet, so that the sponge is likely to have a 'shoulder'.

The general body form of type $b$ is cylindrical to conical, relatively slender and usually taller than wide (Fig. 13). Maximum diameter is generally situated at the base or in the lower part of the sponge body. Transition of the usually flat or slightly convex base to the sides is sharp or subrounded at an angle varying between $90^{\circ}$ and $70^{\circ}$. Transistion of the sides to the hemispherical or conical top is smooth, gradually merging. Apochetes are more extremely irregular with anastomosis and frequently ramification of the passages than those of type $a$. At the top there is a cluster 
of closely packed, randomly arranged, 1-3 mm wide apopores, varying in number between 8 and 15 . Apopores with a more lateral position, at the slope of the top region, usually are connected with apochetes running as grooves along the surface of the sponge body.

In both types, some of the grooves extend along the full height of the body and meet at the base, but most of them anastomose or split up once or twice into smaller grooves. Both the flat and the concave bases usually show a radial or tuberculate pattern. This appearance is produced by a network of numerous, relatively small, irregular, generally radially oriented grooves that commonly anastomose and ramify.

\section{Excurrent system}

The excurrent system is well developed and cannot be studied without involving the external grooves. The system consists of up to $4.0 \mathrm{~mm}$ wide canals (1.5-2.0 $\mathrm{mm}$ on average). Many of the canals are arcuate and consequently run according to the general body form. They ramify and anastomose at irregular intervals and this peculiar feature is characteristic of the genus (Figs. 2, 3, 8, 14). As the body of type $a$ sponges (obconical, flattened top) is usually broader than high, the excurrent canals in peripheral zones have a natural tendency to converge upwards and are more or less concentric to the outside; other canals situated deeper in the sponge body run more or less vertically.

Passages leaving the body laterally continue as a groove and can enter the body again. Peripheral canals approaching the flat sponge base usually rather abruptly turn medially and continue their course for a longer or shorter stretch in a horizontal orientation, parallelling the base (Fig. 4), or piercing the base as a groove and then turning inwards again at some distance. They sometimes extend as far as or even beyond the central point. These features at the base produce a more or less prominent external pattern of radiating grooves, or a more tuberculate aspect.

The excurrent system of the sponges of type $b$ (conical with subrounded top) consists of canals piercing the entire body from base to top and giving off main branches, which in turn may produce irregular and sinuous ramifications in all directions and at any level. The apochetes generally have an almost completely random arrangement, and are at most only slightly arcuate. They rarely follow the outline of the sponge body, but instead descend either perpendicularly or obliquo-vertically from their outlets into the body, anastomosing and ramifying in a haphazard manner, giving offshoots in all directions and sometimes even producing a sort of clews (Figs.
2-3). Canals, having their own outlet at the top, are usually connected more than once in deeper regions of the sponge body (Fig. 14). In the same individual these outlets can vary from dominant and wide, up to $4.0 \mathrm{~mm}$, to rather inconspicuous, being almost as small as the largest incurrent openings, that is, about $1.0 \mathrm{~mm}$. However, some of the excurrent canals situated in the peripheral zone in the conical sponge type, run as well-developed canals concentric to the outside (Fig. 13). This makes it difficult to separate the sponges of both types properly and assign them to different species.

\section{Incurrent system}

The incurrent system is represented by smaller and larger openings, ranging up to $1.0 \mathrm{~mm}$ in diameter and scattered all over the body. The prosochetes are radially arranged and more or less distributed over the entire surface. The diameter of their circular openings range from very small (hardly visible) to $0.75-1.0 \mathrm{~mm}$. This system much resembles that of other members of the family. At the sides, the measured number of prosopores per $\mathrm{cm}^{2}$ is 20 to 30 . However, their varying width and clotting makes it difficult to give precise figures and to distinguish each prosopore. The numerous fine openings at the surface of the sponge body and visible at low magnification do not represent skeletal pores, but are the tiny holes of dissolved skeletal elements, leaving the moulds of their original configuration; larger holes fit the diameter of spherical nodes, smaller ones that of clones.

\section{Skeleton}

The skeleton is composed of spheroclones with 5 to 8 , but mostly 6 , smooth, somewhat tapering clones directed proximally, i.e., towards the interior of the sponge body and a cluster of single or paired thorns directed distally (outwardly). The thorns as a whole give the impression of rootlike protrusions, varying in length, but usually not exceeding $0.02 \mathrm{~mm}$. The arms are provided with shallow cup-shaped terminal expansions, the rims of which are incised randomly, so as to fit around the thorny distal end of the spherical node of a neighbouring element, thus effecting a firm union. The mashes enclosed by three arms each are triangular in shape and range from 0.125-0.250 mm in width. As indicated by ca. 750 measurements, the dimensions of the spheroclones are of the same value as in other European representatives of the family. Table 3 shows the maximum and minimum distances in $\mathrm{mm}$, measured between the centres of the nodes of adjacent elements along any clone lying in a horizontal plane. Spherical nodes range from $0.08-0.12 \mathrm{~mm}$ 
in diameter; the thorny processes from 0.02-0.07 $\mathrm{mm}$. The size of the spheroclones increase radially, from the centre to the periphery (Table 3 ). This phenomenon has been observed also in the genera Carpospongia and Caryospongia (Finks \& Rigby, 2004, p. 134).The skeletal centre of the sponge body, which is also the point of radiation of the inhalant system, is often represented by an irregularly shaped and translucent spot nearly at the centre of the sponge body, apparently a cavity that was filled by silica and in which loose elements may float.

\section{Discussion}

The differences between the two morphologies of $T$. vankempeni gen. et sp. nov. can be summarised as follows:

Type $a$ : relatively large sponge; wider than tall; obconical to subcylindrical; flattened top with cluster of relatively numerous apopores; concave or flat base; rather irregularly excurrent system; relative more concentric apochetes than in type $b$.

Type $b$ : relatively small, slender sponge; as high as wide, or taller than wide; conical to subcylindrical; top conical to hemispherical with relatively few apopores; flat or slightly concave base; concentric apochetes rare or absent; extremely irregular excurrent system.

A single incomplete specimen of T. vankempeni gen. et sp. nov. of type $a$ (Z 25365, from Westerhaar) has two separated clusters of apopores, and remains of a third cluster near the missing part of the sponge. Another specimen from a sandpit near Zwolle (Haerst), in a private collection, has two clusters, left and right from an apical area without apopores. Although this composite-form is rare to this species, the feature of more than one centre of apopores occurs occasionly in many sponge species, which is not surprising, considering they are very simply organized organisms. Only a single incomplete, very irregularly shaped specimen from Itterbeck, west of Wilsum, Germany, in a private collection, has ramifying apochetes, but a subrounded base. One of the sides seems to have overgrown a former original outside and base.

\section{Acknowledgements}

The late Theo van Kempen did the tomographical research and measurements of the material. I thank Christina Franzén - Bengtson, Department of Palaeozoology, Swedish Museum of Natural History (Stockholm); Sara Eliason, Lansmuseet Gotland (Visby); E. W. A. Mulder, Museum Natura Docet
(Denekamp); G. Beersma, Ecodrome Park (Zwolle); as well as the Dutch collectors G. Anninga; J. Bos; A. Drent; R. G. Eggink; J. Jonkman-Ottens; P. van Keulen; T. Koops; J. de Looze; H. Snippe and W. Winterman for loan of material. Especially I am grateful to T. Koops (Emmen); R.G. Eggink (Vroomshoop) and E. W. A. Mulder (Denekamp) for helpful discussions. I also thank Wynanda Koot, Free University (Amsterdam) for preparation of slabs and Jo Vergoossen (Groningen) and Stephen Donovan, Nationaal Natuurhistorisch Museum (Leiden) for improving the English. I am very indepted to the reviewers Diego García Bellido Capdevila, Royal Ontario Museum (Toronto, Canada) and John W. M. Jagt, Natuurhistorisch Museum (Maastricht), for considerable help in improving the paper.

\section{References}

Bassler, R.S., 1927. A new Ordovician sponge fauna. Journal of the Washington Academy of Science 17: 390-394.

Bijlsma, S., 1981. Fluvial sedimentation from the Fennoscandian area into the north-west European Basin during the Late Cenozoic. Geologie \& Mijnbouw 60: 337-345.

De Freitas, T.A., 1991. Ludlow (Silurian) lithistid and hexactinellid sponges, Cape Phillips Formation, Canadian Arctic. Canadian Journal of Earth Sciences 28: 2042-2061

De Laubenfels, M.W., 1955. Porifera. In: R.C. Moore (ed). Treatise on Invertebrate Paleontology, Part E. Geological Society of America and University of Kansas Press (Lawrence, Kansas): 21-112.

Dendy, A., 1924. Porifera 1. Non-Antarctic Sponges. British Antarctic ('Terra Nova') Expedition, 1910, Zoology 6: 269-392.

Duncan, P.M., 1879. On some spheroidal lithistid Spongida from the Upper Silurian Formation of New Brunswick. Annals and Magazine of Natural History (5), 4: 84-91.

Eichwald, E., 1830. Phytozoen. In: Naturhistorische Skizze von Lithauen, Volhynien und Podolien. (Wilna): 186-191.

Finks, R.M., 1960. Late Paleozoic sponge faunas of the Texas region: the siliceous sponges. American Museum of Natural History Bulletin 120: 1-160.

Finks, R.M. \& Rigby, J.K., 2004. Paleozoic Demosponges. In: Kaesler, R. L. (ed): Treatise on Invertebrate Paleontology, Part E, Porifera revised, 3. Geological Society of America and University of Kansas (Boulder, Colorado and Lawrence, Kansas): 1-173.

Goldfuss, A., 1826. Petrefacta Germaniae oder Abbildungen und Beschreibungen der Petrefacten Deutschlands und der angrenzenden Länder, 1, 1 (Düsseldorf): 1-76.

Grant, R.E., 1836. Animal Kingdom. In: Todd, R. B. (ed): The Cyclopaedia of Anatomy and Physiology, 1. Sherwood, Gilbert \& Piper (London): 107-118.

Hinde, G.J., 1883. Catalogue of the fossil sponges in the Geological Department of the British Museum (Natural History). British Museum (Natural History) (London): $248 \mathrm{pp}$.

Hinde, G.J., 1887-1912. A monograph of the British fossil sponges. Parts I and II. Palaeontographical Society (London): $188 \mathrm{pp.}$

Johns, R.A., 1994. Ordovician lithistid sponges of the Great Basin. Nevada Bureau of Mines and Geology, NBMG Open-file Report 94-1: 1-199. 
Klöden, K.F., 1834.Die Versteinerungen der Mark Brandenburg, insonderheit diejenigen, welche sich in den Rollsteinen und Blöcken der südbaltischen Ebene finden. Lüderitz (Berlin): $381 \mathrm{pp}$.

Krueger, H.H., 1994. Die nordische Geröllgemeinschaft aus der Lausitz (Miozän) und deren Vergleich mit Sylt. Brandenburger geowissenschaftliche Beiträge 1: 84-89.

Laban, C., 1995. The Pleistocene glaciations in the Dutch sector of the North Sea. A synthesis of sedimentary and seismic data. Ph D Thesis, University of Amsterdam: 194 pp.

Lévi, C., 1953. Sur une nouvelle classification des Démosponges. Académie des Sciences (Paris), Comptes Rendus des séances 236: 853-855.

Lindström, G., 1888. List of the Fossil Faunas of Sweden. I. Cambrian and Lower Silurian. 24 pp.; II. Upper Silurian. 29 pp. (Stockholm).

McKerrow, W.S., Dewey, J.F. \& Scotese, C.R., 1991. The Ordovician and Silurian Development of the Iapetus Ocean. Special Papers in Palaeontology 44: 165-178.

Miller, S. A., 1889. Class Porifera. In: North American Geology and Paleontology. (Cincinatti): 152-167.

Oswald, F., 1847. Ueber die Petrefacten von Sadewitz. Uebersicht der Arbeiten und Veränderungen der schlesischen Gesellschaft für vaterländische Kultur im Jahre 1846: 56-65.

Overeem, I., Weltje, G.J., Bishop-Kay, C. \& Kroonenberg, S.B., 2001. The Late Cenozoic Eridanos delta system in the southern North Sea Basin: a climate signal in sediment supply? Basin Research 13: 293-312.

Quenstedt, F.A., 1878. Petrefactenkunde Deutschlands 5. Korallen (Schwämme). Fues's Verlag (Leipzig): 558 pp.

Rauff, H., 1893-1894. Palaeospongiologie. Erster oder allgemeiner Theil und Zweiter Theil, erste Hälfte. Palaeontographica 40: 1-346; 41: 347-395.

Raymond, P.E., \& Okulitch, V.J., 1940. Some Chazyan sponges. Bulletin of the Museum of Comparative Zoology at Harvard College 86: 197-214.

Rhebergen, F. \& Von Hacht, U., 1996. De Ordovicische sponzenfauna uit Nederland en het Duitse grensgebied en de vergelijking ervan met de sponzen van Sylt, de Lausitz en Gotland. Grondboor \& Hamer 50: 83-94.

Rhebergen, F. \& Von Hacht, U., 2000a. Schismospongia syltensis gen. n. sp.n. (Porifera), ein neuer Geschiebeschwamm aus plio/ pleistozänen Kaolinsanden von Sylt (Nordwest-Deutschland). Archiv für Geschiebekunde 2: 797-804.

Rhebergen, F. \& Von Hacht, U., 2000b. Ordovician erratic sponges from Gotland, Sweden. GFF 122: 339-349.

Rhebergen, F., Eggink, R.G., Koops, T. \& Rhebergen, B., 2001. Ordovicische zwerfsteensponzen. Staringia 9 (Grondboor en Hamer 55, 2): 1-144.

Rigby, J.K., 2004. Classification. In: Kaesler, R. L. (ed):Treatise on Invertebrate Paleontology, Part E, Porifera revised, 3. Geological Society of America and University of Kansas (Boulder, Colorado and Lawrence, Kansas): 1-8.

Rigby, J.K. \& Webby, B.D., 1988. Late Ordovician Sponges from the Malongulli Formation of central New South Wales, Australia. Palaeontographica Americana 56: 1-147.
Roemer, F, 1848. Über eine neue Art der Gattung Blumenbachium (König) und mehrere unzweifelhafte Spongien in obersilurischen Kalkschichten der Grafschaft Decatur im Staate Tennessee in Nord-Amerika. Neues Jahrbuch Mineralogie, Geologie und Paläontologie 1848: 680-686.

Roemer, F, 1860. Die silurischen Fauna des westlichen Tennessee. Eine palaeontologische Monographie. Edward Trewent Verlag (Breslau): $97 \mathrm{pp}$.

Roemer, F. 1861. Die fossile Fauna der Silurischen DiluvialGeschiebe von Sadewitz bei Oels in Nieder-Schlesien. (Breslau): $\mathrm{xvi}+82 \mathrm{pp}$.

Schlüter, C.A., 1884. Über Astylospongia Gothlandica sp. n. Verhandlungen des Naturhistorischen Vereines der preussischen Rheinlande und Westfalens, 41 (5) 1:79-80.

Schmidt, O., 1870. Grundzüge einer Spongien-Fauna des atlantischen Gebietes. (Jena. Leipzig): iv $+88 \mathrm{pp}$.

Sollas, W. J., 1875. Sponges. Encyclopedia Brittanica, 9th ed. Adam \& Charles Black (Edinburgh): 427-446.

Ulrich E.O. \& Everett, O., 1890. Lower Silurian Sponges. Illinois Geological Survey (Paleontology of Illinois, 2, 5), Bulletin 8: 255-282.

Van Kempen, T.M.G., 1978. Anthaspidellid sponges from the Early Paleozoic of Europe and Australia. Neues Jahrbuch für Geologie und Paläontologie, Abhandlungen 156: 305-337.

Van Kempen, T.M.G., 1989. On a new anthaspidellid sponge from the Baltic Early Paleozoic. Mitteilungen aus dem GeologischPaläontologischen Institut der Universität Hamburg 68: 131-157.

Van Kempen, T.M.G., 1990. Two Baltic Ordovician chiastoclonellids (Porifera) from the island of Sylt (NW Germany). In: Von Hacht, U., (ed): Fossilien von Sylt III. Verlag I.-M. von Hacht (Hamburg): 151-178.

Von Hacht, U., 1981. Syltrochos pyramidoidalis, eine neue oberordovizische Spongie aus der Braderuper Serie der Kaolinsande von Sylt. Grondboor en Hamer 35: 154-155.

Von Hacht, U., 1985. Sedimentärgeschiebe im Kaolinsand von Sylt unter besonderer Berücksichtigung verkieselter Spongien. In: Von Hacht, U. (ed): Fossilien von Sylt. Verlag I.-M. von Hacht (Hamburg): 25-42.

Von Hacht, U., 1994. Sponzentelling op Sylt. Grondboor en Hamer 48: 76-80.

Von Hacht, U., \& Rhebergen, F., 1996. Sponzentelling van Sylt II. Grondboor en Hamer 50: 12-16.

Von Hacht, U., \& Rhebergen, F., 1997. Ordovizische Geschiebespongien Europas. In: Zwanzig, M. \& Löser, H. (eds): Berliner Beiträge zur Geschiebeforschung. CPress Verlag (Dresden): 51-63.

Wiman, C., 1901. Über die Borkholmer Schicht im Mittelbaltischen Silurgebiet. Bulletin of the Geological Institution of the University of Upsala 5, 2 (1902): 149-221.

Zandstra, J.G., 1971. Geologisch onderzoek in de stuwwal van de oostelijke Veluwe bij Hattem en Wapenveld. Mededelingen van de Rijks Geologische Dienst 22: 215-260.

Zittel, K.A., 1877. Beiträge zur Systematik der fossilen Spongien. Neues Jahrbuch für Mineralogie, Geologie und Paläontologie 1877 (1): 337-378. 